\title{
SOSIALISASI DAN INTERNALISASI DALAM PEMBELAJARAN DRUM ANAK-ANAK \\ (Studi Kasus Pengajaran Drum di Lembaga Kursus Musik West Brothers)
}

\section{Indra Permana}

Bassis dan pengajar musik untuk anak-anak di Solo

\begin{abstract}
This paper begins with an interest in seeing the musical abilities of children learners of non-formal institutions of West Brothers music course in playing the drum, where the children show "maturity" in the musical. The level of difficulty, the selection of song repertoire, and the stage action presented by the children tends to resemble drum players of adolescence and adulthood. This raises a question about socialization and internalization in learning.

West Brothers as an educational institution becomes a place of transmission of knowledge, skills, and values from educators to learners. In the process of transmission, there is socialization and internalization through social interaction in drum learning activities. This research aims to know how the form of socialization and internalization in the drum learning process in West Brothers, especially in children learners, and how the process of socialization and internalization that form behavior patterns manifest in the musical ability of children playing drum musical instruments. This paper reveals that child behavior patterns embodied in the ability and taste of musical drumming are influenced and shaped through the process of interaction between learners and teachers in the West Brothers environment, including socialization and internalization.
\end{abstract}

Kata kunci : sosialisasi dan internalisasi, west brothers, kursus drum solo

\section{Kursus Musik di West Brothers}

Dewasa ini musik telah menjadi salah satu kebutuhan yang dianggap penting bagi setiap individu masyarakat, terutama masyarakat perkotaan. Dalam perkembangannya, musik tidak hanya dijadikan sebagai pemenuhan bagi kebutuhan hiburan meliputi kesenangan, rasa suka, nikmat, puas, gembira melainkan juga merupakan sarana untuk mengungkapkan nilai estetis dari masingmasing individu sebagai ungkapan kreatif masyarakatnya.

Kebutuhan akan musik tampaknya juga disadari oleh sebagian masyarakat. Hal tersebut terlihat pada berkembangnya keberadaan lembaga-lembaga kursus musik non formal di kota Solo seperti West 
Brothers, Purwacaraka, Gilang Ramadhan School, YMI, Carmesha, Melodia, Rhytm Stars, Elfa dan sebagainya. Adapun masingmasing lembaga-lembaga kursus musik tersebut memiliki beragam program dan harga yang ditawarkan.

Di antara banyaknya lembaga kursus musik yang ada di kota Solo tersebut salah satunya adalah West Brothers, yang memiliki keunggulan program pementasan paling intens serta harga kursus yang relatif paling murah. West Brothers hadir di tengah masyarakat sebagai sebuah pranata pendidikan menyediakan sumber-sumber daya lingkungan untuk mengakomodasi kebutuhan pendidikan sebagai proses transmisi budaya. Proses transmisi budaya tersebut dilakukan oleh pendidik dan penerimaan yang dilakukan oleh peserta didik, bertalian dengan kebudayaan agar dapat dijadikan pedoman hidup (Rohidi, 1994).

West Brothers hadir pertama kali di kota Solo pada tahun 2002 dengan bentuk usaha rental studio musik dan permainan video game playstation. Dikelola oleh tiga musisi bersaudara yaitu Bayu Amarendra (Bayu), Haryo Dananjoyo Aditya Bhawono (Ryo), dan Suryo Banu Arum Kunto Wibowo (Banu) yang tergabung dalam satu kelompok band West Gate. Adapun nama West Gate (gerbang barat) diambil dari penamaan lokasi tempat tinggal mereka yaitu di komplek Istana Mangkunegaran sebelah barat, tepatnya di samping gerbang atau gapura barat, yang kemudian juga melatarbelakangi penamaan West Brothers.

Keberadaan West Brothers tidak hanya dijadikan sebagai wadah interaksi belajar mengajar antara pengajar dengan peserta didik dalam mencapai kemampuan berketerampilan musik. Berkumpulnya individu-individu di dalamnya yang memiliki kesamaan minat, ide, dan wilayah atau lokasi berkumpul dan berinteraksi juga menjadikan West Brothers sebagai sebuah komunitas 1. Komunitas tersebut terbentuk oleh rutinitas pertemuan dan interaksi antar individu-individu di dalamnya dalam sebuah lingkungan kegiatan bermusik.

\section{Metode Pembelajaran Drum di West Brothers}

West Brothers dalam proses pembelajaran alat musik drum tidak memiliki tuntutan standart kurikulum tertentu. Setiap pengajar diberikan kebebasan dalam menerapkan metode pengajarannya terhadap peserta didiknya berdasarkan pengalaman masing-masing dalam belajar alat musik drum. Adapun materi pembelajaran pengenalan teknik dasar seperti yang telah diuraikan di atas disamakan berdasarkan kesepakatan antar pengajar, yang selanjutnya dikembangkan dengan cara masing-masing pengajar. 
Namun apa yang penulis lihat di dalam kegiatan proses kegiatan belajar mengajar khususnya alat musik drum di West Brothers, meskipun tanpa melalui kesepakatan semua pengajar memiliki kesamaan dalam menerapkan metode pembelajarannya yaitu dengan mengguna kan aliran humanistik.

Aliran humanistik di West Brothers lebih menekankan pada motivasi dalam diri peserta didik yang diperoleh melalui pendekatan alamiah tidak kaku dari pengajar terhadap peserta didik. Seorang pengajar selain berusaha menyampaikan materi kognitif juga melakukan penggalian motivasi dan emosi peserta didiknya. Teori belajar humanistik berusaha memahami perilaku belajar dari sudut pandang pelakunya, bukan dari sudut pandang pengamatnya (Uno, 2006).

Adapun dalam proses interaksi belajar mengajar alat musik drum di West Brothers lebih banyak menerapkan aspek motorik lewat dua bentuk metode pembelajaran meliputi metode demonstrasi yaitu pengajar memperagakan teknik bermain drum kepada peserta didiknya yang kemudian untuk ditirukan, dan metode latihan (training) yaitu peserta didik mengerjakan apa yang sudah diperagakan oleh pengajar melalui pembiasaan yang berulang-ulang.

Di dalam pelaksanaan kedua metode tersebut juga disisipi penyampaian sedikit materi menyangkut aspek kognitif seperti membaca notasi ritmis yang disederhana kan. Selain itu juga pada saat proses latihan bersama, peserta didik juga diajarkan aspek afektif seperti sikap menghargai kebersama an, kedisiplinan waktu, rasa tanggung jawab, saling menghargai sesama pemain dalam satu kelompok bermain musik bersama.

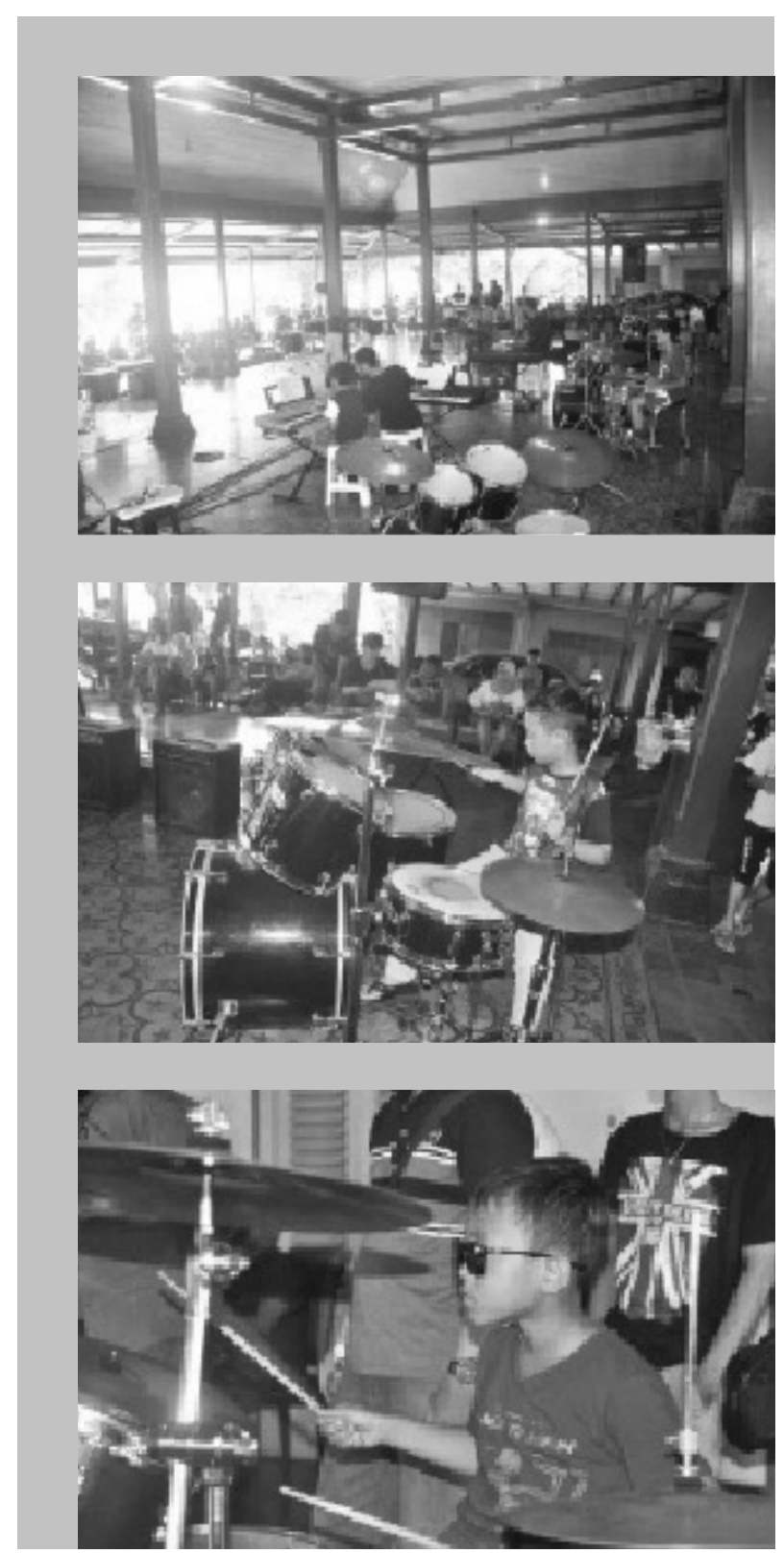




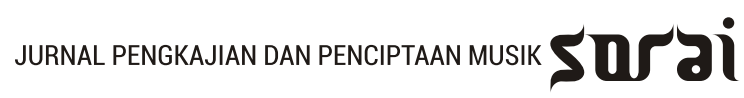

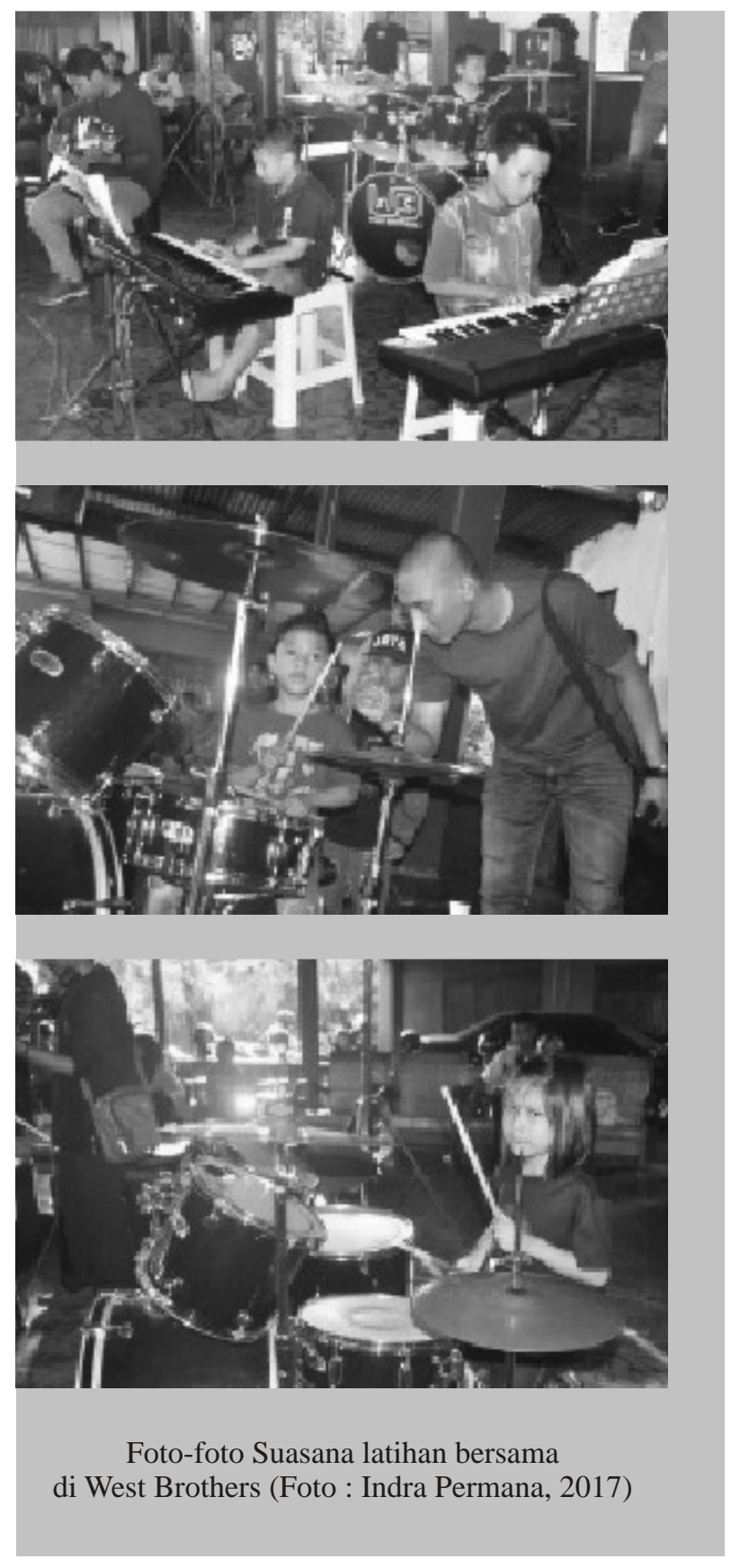

\section{Minat Anak terhadap Alat Musik Drum}

Peserta didik kursus alat musik drum di West Brothers $90 \%$ merupakan usia anak meliputi usia pra sekolah hingga usia TK, SD, dan SMP. Hal ini menunjukkan bahwa alat musik drum sangat diminati oleh anakanak. Berdasarkan data yang telah diperoleh dari bagian administrasi West Brothers, dapat diidentifikasikan perbandingan jumlah peserta didik drum berdasarkan usia sekolah. Peserta didik usia SD yang menjadi sasaran penelitian ini mendominasi jumlah peminat drum di West Brothers. Berikut adalah tabel jumlah peserta didik drum yang terdaftar aktif di West Brothers berdasarkan usia sekolah.

\begin{tabular}{|c|l|c|}
\hline No & Usia Sekolah & $\begin{array}{c}\text { Jumlah } \\
\text { peserta didik }\end{array}$ \\
\hline 1 & Pra sekolah & 5 orang \\
\hline 2 & TK & 13 orang \\
\hline 3 & SD & 63 orang \\
\hline 4 & SMP & 8 orang \\
\hline 5 & SMA & 3 orang \\
\hline
\end{tabular}

Tabel daftar jumlah peserta didik drum

Pada dasarnya berkesenian tidak dapat dipaksakan termasuk pada anak-anak peserta didik drum di West Brothers. Alat musik drum menjadi sarana untuk bermain sekaligus mengungkapkan ekspresi melalui bunyi-bunyi yang dihasilkan dengan irama tertentu. Minat anak pada alat musik drum cukup tinggi di West Brothers. Salah satunya adalah peserta didik drum bernama Ibrahim, menurut penuturan orang tuanya bahwa sejak kecil Ibrahim sudah mulai menunjukkan ketertarikannya pada alat 
musik drum. Hal ini ditunjukkan Ibrahim saat menonton acara-acara musik yang ditayangkan di televisi, dimana dia sering menirukan gerakan tangan memainkan drum. Kemudian di usia TK Ibrahim mulai diikutkan kegiatan kursus drum di West Brothers untuk lebih dikenalkan dan diarahkan untuk memiliki kemampuan bermain alat musik drum. Ibrahim pernah mengikuti beberapa ajang kompetisi drum tingkat junior. Salah satunya pernah menjuarai kompetisi drum junior yang diselenggarakan oleh produk cymbal merek ternama Zildjian.

Lain halnya dengan Rasya (kelas 4 SD), ayahnya yang bernama Indra merupakan seorang mantan vokalis band indie dari Solo Vanilla dan pernah menjadi salah satu kontestan 10 besar ajang kompetisi vokal Indonesian Idol pada tahun 2008. Indra menginginkan anaknya tersebut untuk belajar vokal di West Brothers agar bisa memiliki kemampuan menjadi seorang penyanyi seperti dia. Namun Rasya lebih menaruh atensi dan minat pada alat musik drum daripada vokal dan pada akhirnya Rasya didaftarkan di kelas instrumen drum.

Begitu juga dengan kebanyakan peserta didik drum lainnya di West Brothers, dari perbincangan dengan beberapa orang tua mengatakan bahwa kursus musik di West Brothers merupakan dorongan inisiatif dari orang tua yang ingin mengarahkan anak- anaknya untuk bisa memiliki kemampuan keterampilan bermain musik, yang mana tidak dapat terpenuhi di sekolah formal. Adapun untuk pemilihan alat musik yang ingin dipelajari dalam hal ini alat musik drum berasal dari pilihan anak itu sendiri tanpa adanya paksaan dari orang tua atau siapapun.

Kegiatan bermain drum dianggap sebagai suatu permainan yang seru dan menyenangkan dimana ekspresi dan energi dapat mereka tuangkan ke dalam permainan alat musik drum dengan segala ragam warna bunyi yang dihasilkan. Pengalaman estetis melalui pembelajaran bermain drum akan menjadikan anak mudah menerima dan mengekspresikan kembali secara kreatif ke dalam keterampilan motoriknya memainkan alat musik drum dan menghasilkan bunyi ritmis yang estetis.

\section{Tahap Sosialisasi dalam Pembelajaran}

Dalam perkembangan sosialnya, seorang anak sebagai individu juga mengalami fase berada di suatu tempat sebagai sarana untuk mendapatkan pembentukan sikap dan perilaku sesuai dengan lingkungan anak tersebut berada. Salah satu tempat atau lingkungan tersebut adalah West Brothers dimana anak memiliki peran sebagai peserta didik dan pemain drum dengan mendapatkan pengetahuan dan keterampilan bermain drum. Mengacu 
pada pendapat Mead (dalam Maryati dan Suryawati, 2006:99) bahwa sosialisasi yang dilalui seseorang dapat dibedakan melalui beberapa tahapan, yaitu :

\section{Tahap persiapan (Preparatory Stage)}

Tahap ini dialami seorang anak saat mempersiapkan diri untuk mengenal dunia sosialnya, termasuk untuk memperoleh pemahaman tentang diri. Pada tahapan ini anak mulai melakukan kegiatan meniru meskipun tidak sempurna. Sebagaimana yang dialami oleh salah satu peserta didik drum di West Brothers bernama Ibrahim, orang tuanya menceritakan bahwa sebelum dimasukkan kursus musik di West Brothers, saat Ibrahim usia pra sekolah di rumah sering menirukan permainan drum yang dilihatnya melalui layar kaca televisi dengan memanfaatkan ember dan panci yang dipukul dengan menggunakan sendok layaknya seorang pemain drum.

Seperti halnya pada seorang anak berusia 5 tahun bernama Mossa yang sering ikut menemani kakaknya yang bernama Arsya (kelas 4 SD) belajar alat musik drum di West Brothers. Penulis menangkap aktivitas Mossa melalui rekaman video yang menunjukkan Mossa saat menyaksikan kakaknya bermain drum di acara pementasan West
Brothers memainkan drum lagu "Nightmare" karya band rock Avenged Sevenfold. Tampak Mossa dari samping panggung menirukan kakaknya yang sedang bermain drum dengan menggerakkan tangannya memegang stik mengikuti irama lagu rock yang dimainkan oleh kakaknya tersebut. Bahkan dengan percaya diri Mossa naik ke atas panggung, tampak asyik menikmati serta melakukan gerakan tangan menirukan kakaknya mengikuti irama lagu. Apa yang ditunjukkan oleh Mossa tersebut adalah proses sosialisasi di tahap persiapan (preparatory stage). Menurut orang tuanya, saat di rumah Mossa juga sering meminta orang tuanya untuk memutarkan video musik rock seperti yang dimainkan kakaknya tersebut.

Dalam perbincangan penulis dengan salah seorang orang tua peserta didik di West Brothers, yaitu Adhi atau biasa dipanggil Mas Londho (Pemilik warung Timlo Maestro Solo) yang juga merupakan mantan pemain drum band lokal kota Solo beraliran rock funk Sastro band. Menuturkan bahwa anaknya yang bernama Farrel sejak kecil sering melihat foto dan rekaman video ayahnya bermain drum saat masih bersama Sastro band. Kemudian mulai menunjukkan ketertarikannya dengan 
alat musik drum dan sering menirukan gerakan bermain drum seperti yang diperagakan ayahnya di rekaman video tersebut. Proses yang berlangsung ini merupakan tahapan awal atau persiapan bagi Farrel dalam bersosialisasi lewat interaksi dengan individu-individu lain di dalam rumah atau lingkungan keluarga. Kemudian Farrel dimasukkan ke dalam lembaga kursus musik West Brothers dimana dia melakukan proses sosialisasi ke tahap selanjutnya, yaitu berinteraksi dengan lingkungan luar rumahnya dalam tahap play stage.

\section{Tahap meniru (Play Stage)}

Tahap ini ditandai dengan semakin sempurnanya seorang anak menirukan peran-peran yang dilakukan oleh orang dewasa. Anak mulai dikenalkan dengan lingkungan luar rumah atau keluarga untuk menumbuhkan kesadarannya sebagai mahkluk sosial. Seperti pada Ibrahim pada saat mulai menginjak usia sekolah dasar kelas satu, dia kemudian dimasukkan ke lembaga kursus musik West Brothers untuk lebih dikenalkan dengan pengetahuan dan keterampilan bermain alat musik drum. Di tahapan ini

Ibrahim mulai menyerap nilai dan norma berupa pengetahuan bermain drum dari orang yang dianggapnya penting atau berarti yaitu Eros sebagai pengajar drumnya. Ibrahim mendapatkan pengajaran dasar-dasar bermain drum mulai dari cara memegang stik, memukul perangkatperangkat instrumen dalam drum set, dan cara menginjak pedal dalam menghasilkan bunyi dari bass drum. Selain itu juga diajarkan aturan-aturan dan nilai dalam bermain alat musik drum seperti pola irama, birama, tempo, dinamika yang akan menghasilkan bunyi ritmis estetis sehingga Ibrahim mulai belajar merasakan dan mendefinisikan keindahan bunyi dalam berbagai jenis irama dan genre musik.

Peniruan yang dilakukan Ibrahim terhadap pengajarnya tersebut tidak hanya sekedar pada teknik dan gaya permainan drum saja, melainkan juga dalam hal selera musik, Ibrahim ikut menggemari jenis musik blues karena sering menyaksikan Eros tampil bermain drum di acara-acara musik blues bersama komunitas Blues Brothers Solo (BBS) - salah satu komunitas yang terbentuk di dalam West Brothers.

\section{Tahap siap bertindak (Game Stage)}

Pada tahapan ini peniruan yang dilakukan oleh seorang anak sudah mulai berkurang dan digantikan oleh peran yang secara langsung dimainkan 
oleh si anak tersebut dengan penuh kesadaran. Dalam proses pembelajaran drum di West Brothers, tahap ini ditunjukkan pada saat Ibrahim mulai berinteraksi dengan lebih banyak orang, yakni pada saat mulai ikut dalam kegiatan latihan bersama dengan sebuah kelompok band yang dibentuk oleh West Brothers. Selama berlangsung proses interaksi tersebut Ibrahim sadar dalam memainkan peran sebagai pemain drum (drumer) serta memahami aturan-aturan dan norma yang berlaku dalam kelompok band tersebut. Selain dirinya juga terdapat individu lain yaitu pemain gitar, pemain bass, pemain keyboard, dan penyanyi. Ibrahim juga memahami alat musik drum yang dimainkannya tersebut memiliki fungsi dan peran penting untuk menjaga tempo dan membentuk irama pada lagu yang dimainkan bersama intrsumen lainnya. Selain itu juga pengetahuan mengenai pengaturan dinamika pola permainan drum yang perlu diatur sedemikian rupa agar tercipta keharmonisan dengan permainan instrumen lainnya termasuk nyanyian vokal. Ibrahim mulai mengembangkan pengetahuannya yang berkaitan dengan alat musik drum dan lagu-lagu yang dimainkannya secara mandiri dengan mencari referensireferensi lain lewat internet.

\section{Tahap penerimaan norma kolektif (Generalized Stage)}

Pada tahap ini seseorang telah dianggap dewasa yaitu sudah menyadari pentingnya sebuah peraturan. Ibrahim meskipun di usia kelas 6 SD sudah dianggap ,dewasa? secara musikal, dimana kemampuan bermain drumnya tidak kalah dengan orang dewasa. Maka dengan segala kematangan dan kesiapannya tersebut, Ibrahim diikutsertakan dalam kegiatan musik bersama orang dewasa meskipun dengan motivasi yang berbeda. Beberapa pengalaman pentas yang pernah diikuti oleh Ibrahim diantaranya Solo Blues festival 2015 di Benteng Vastenberg Solo, Blues on Stage Bentara Budaya di Balai Soedjatmoko Solo, dan Tribute Sheila On 7 yang diselenggarakan oleh West Brothers. Selain itu Ibrahim juga sering ikut tampil secara spontanitas di beberapa tempat kuliner Eros "ngamen" bermain drum bersama bandnya. Pada tahap ini Ibrahim sudah menunjukkan „kedewasaan?nya dalam bermain drum dimana dia sudah memiliki kemampuan untuk bekerja sama bermain musik bersama dalam satu kelompok band.

Melalui tahapan-tahapan sosialisasi yang dilalui oleh anak-anak peserta didik drum 
tersebut, terutama pada tahap meniru (Play Stage) dapat diketahui bahwa kegiatan pembelajaran drum di West Brothers melalui proses interaksi telah membentuk pola perilaku dan sikap anak dalam wujud permainan musik.

\section{Jenis dan Tipe Sosialisasi dalam Pembelajaran Drum}

a. Sosialisasi sekunder

West Brothers merupakan sebuah intitusi yang di dalamnya terdapat sejumlah individu dalam situasi yang sama dalam jangka waktu tertentu bersama-sama menjalani aturan-aturan yang berlaku. Sosialisasi berlangsung di dalam rutinitas kegiatan belajar mengajar alat musik drum. Adapun berdasarkan jenisnya sosialisasi dibedakan menjadi dua jenis, yaitu sosialisasi primer dan sosialisasi sekunder. Sosialisasi primer adalah dimana seorang individu menjalani sosialisasi pertama kalinya dengan belajar menjadi anggota masyarakat dalam keluarganya di rumah. Anak mulai mampu membedakan dirinya dengan orang lain di lingkungan keluarganya. Sedangkan sosialisasi sekunder merupakan kelanjutan dari sosialisasi primer yaitu seorang anak mulai diperkenalkan ke dalam kelompok tertentu dalam masyarakat.
Proses pembelajaran drum di West Brothers merupakan bentuk sosialisasi sekunder dimana anak sebagai individu masyarakat dalam hal ini peserta didik drum bersosialisasi di luar lingkungan keluarganya yakni di lingkungan West Brothers untuk mendapatkan pengetahuan dan keterampilan bermain alat musik drum. Kepribadian anak yang sudah terbentuk di lingkungan keluarga melalui sosialisasi primer kemudian dihadapkan pada situasi dan lingkungan di West Brothers yang berbeda dengan di rumah, dan anak tersebut berinteraksi dengan individu-individu lain yang juga berbeda dengan individu di dalam lingkungan keluarganya.

Dalam jangka waktu tertentu sosialisasi sekunder yang berlangsung di dalam kegiatan pembelajaran drum di West Brothers tersebut membentuk suatu proses resosialisasi yaitu pemberian identitas diri yang baru bagi anak. Saat di rumah berada di lingkungan keluarga menjadi anggota keluarga sebagai anak, adik atau kakak kemudian saat berada di lingkungan West Brothers mendapatkan identitas diri yang baru menjadi anggota masyarakat West Brothers sebagai peserta didik, pemain drum atau anak band. Secara bertahap melalui kegiatan bermusik, seorang anak mampu 
membedakan peran dirinya dengan orang lain di lingkungan West Brothers, yaitu dengan peserta didik instrumen lainnya seperti gitar, keyboard, biola dan sebagainya atau dengan musisi-musisi yang berada di West Brothers baik pengajar maupun bukan pengajar.

\section{b. Sosialisasi informal}

Di dalam sosialisasi terdapat dua tipe yang berkaitan dengan perbedaan standar dan nilai. Sebagai contoh di sekolah seorang anak disebut baik jika nilai test tertulis dan prakteknya di atas delapan atau tidak pernah terlambat masuk sekolah. Sementara di West Brothers seorang anak atau peserta didik drum disebut baik jika mampu menampilkan permainan drum sesuai dengan apa yang diajarkan oleh pengajar serta bisa menghargai sesama anggota komunitas West Brothers. Tipe tersebut terdiri dari sosialisasi formal dan informal. Sosialisasi formal terjadi melalui lembaga-lembaga yang berwenang menurut ketentuan yang berlaku dalam negara, seperti di pendidikan sekolah dan pendidikan militer. Sedangkan sosialisasi informal terdapat di masyarakat atau komunitas yang bersifat kekeluargaan seperti di West Brothers. Sosialisasi tipe informal ini tampak sekali pada kegiatan pementasan yang diselenggarakan oleh West Brothers. Pencapaian seorang anak setelah melalui proses belajar dan latihan bermain drum hingga mengalahkan rasa takut dan malunya untuk berani tampil di atas panggung dengan ditonton banyak orang, sudah merupakan nilai prestasi bagi anak tersebut. Adapun pencapaian yang dialami oleh peserta didik tersebut mendapatkan apresiasi tinggi dari pengajar drumnya dan para musisi di West Brothers.

Satu contoh kasus, dalam sebuah kegiatan latihan bersama di West Brothers, Oscar menuturkan bahwa ada salah satu peserta didiknya sebut saja bernama Boy yang dipilih menjadi pemain drum. Pada saat latihan Boy ditegur oleh pengajarnya karena permainan drumnya sering keluar dari tempo dan cenderung sengaja melakukan aksi berlebihan dengan pola permainan yang tidak sesuai dengan yang diajarkan oleh pengajar, sehingga membuat bingung pemain lainnya seperti pada gitar, keyboard, bass, apalagi vokalis. Namun pada saat ditegur Boy tersebut malah balik menyalahkan bahkan memaki-maki vokalisnya. Pada akhirnya pengajar mencoret nama Boy dari daftar pemain drum. Keesokan harinya orang tuanya 
melakukan protes keras kepada si pengajar dengan mengatakan bahwa anaknya Boy tersebut memiliki nilai terbaik pelajaran musik di sekolahnya, dan pernah menjuarai beberapa kali lomba drum anak. Pada kasus tersebut terjadi perbedaan standar dan nilai. Orang tua Boy melihat penilaian berdasarkan data statistik di sekolah dan piagam penghargaan, sedangkan di West Brothers tidak sekedar tingkat kemampuan yang menjadi bahan penilaian melainkan juga sikap dan perilaku peserta. Dengan seiringnya waktu kemudian Boy memiliki kesadaran dalam dirinya untuk menilai dirinya sendiri dan kemudian dia menunjukkan perubahan sikap dan perilaku dalam kegiatan belajar mengajar drum di West Brothers. Tipe sosialisasi informal seperti ini yang berlangsung di West Brothers, melalui interaksi dalam kegiatan belajar mengajar alat musik drum telah memberikan kesadaran kepada peserta didiknya tentang peranan apa yang harus ia lakukan.

\section{West Brothers sebagai Agen Sosialisasi}

Agen sosialisasi adalah pihak-pihak yang menyelenggarakan atau melaksanakan sosialisasi, meliputi keluarga, kelompok bermain atau teman pergaulan, media massa, lembaga pendidikan sekolah formal, dan lembaga non formal dalam masyarakat. Termasuk West Brothers sebagai lembaga pendidikan non formal kursus musik merupakan agen sosialisasi yang memiliki pengaruh dalam keberlangsungan sosialisasi. Keberadaan West Brothers sebagai agen sosialisasi membantu seorang individu atau peserta didik dalam membentuk pandangannya sendiri tentang dunianya yakni dunia musik dan membuat penilaian mengenai tindakan-tindakannya sebagai seorang musisi pemain drum.

Adapun di dalam West Brothers juga terdapat agen sosialisasi lain yaitu teman pergaulan atau teman bermain, sehingga ada agen di dalam agen. Selain interkaksi antara satu pengajar dengan satu peserta didik di dalam aktivitas belajar mengajar drum, di West Brothers juga terdapat proses interaksi antara peserta didik dengan peserta didik lain yang sebaya yang mana telah menciptakan suatu kelompok bermain. Kelompok bermain tersebut ikut berperan dalam membentuk kepribadian seorang individu. Sosialisasi dalam kelompok bermain antar peserta didik dilakukan dengan cara mempelajari pola interaksi dengan peserta didik drum lainnya yang sederajat dengan dirinya. Seorang anak atau peserta didik di West Brothers dapat mempelajari peraturan yang mengatur peranan orang-orang yang kedudukannya 
sederajat dengannya yaitu sebagai peserta didik alat musik drum atau sebagai pemain drum (drumer).

\section{Internalisasi dalam}

\section{Pembelajaran Drum di West Brothers}

\section{Pembelajaran Drum sebagai \\ Internalisasi}

Internalisasi merupakan salah satu cara dalam menyelenggarakan sosialisasi. Seperti pada teori Broom dan Markoem dalam Rohidi (1994) menyatakan bahwa ada tiga cara yang dapat ditempuh dalam proses sosialisasi yaitu pelaziman (conditioning), imitasi/ identifikasi ( modelling), dan internalisasi (internalisation). Secara etimologis dalam Kamus Besar Bahasa Indonesia (1989 : 336) internalisasi adalah penghayatan, pendalaman, penguasaan secara mendalam yang berlangsung melalui binaan, bimbingan dan sebagainya. Maka internalisasi dalam kegiatan belajar mengajar alat musik drum merupakan suatu proses penanaman sikap ke dalam pribadi peserta didik melalui bimbingan pengajaran sehingga terwujud pola perilaku yang tercermin dalam bentuk permainan drum dan repertoar lagu yang dimainkan. Sedangkan kaitannya dengan proses pembelajaran, internalisasi dapat diartikan sebagai sebuah proses penghayatan, proses penguasaan secara mendalam, berlangsung melalui penyuluhan, latihan, penataran atau pengkondisian tertentu lainnya (Depdikbud dalam Rohidi 1994). Internalisasi berlangsung lewat sebuah proses yang bersifat pribadi dalam pengembangan diri melalui pembelajaran alat musik drum.

Sebagai suatu proses pendidikan, internalisasi mengakui bahwa setiap individu peserta didik memiliki potensi di dalam dirinya yang bisa dikembangkan. Begitu pula di West Brothers melalui pendekatan humanistik, internalisasi diperlukan untuk membantu upaya pembentukan karakter kepribadian anak yang tercermin dalam permainan alat musik drum.

Internalisasi dalam kegiatan pembelajaran drum di West Brothers merupakan kelanjutan dari sosialisasi yang dijalani oleh peserta didik, setelah memperoleh pengetahuan dan keterampilan bermain drum melalui kegiatan belajar mengajar kemudian interaksi sosial berlanjut pada internalisasi yang diperoleh melalui penanaman nilai dan pemahaman lebih mendalam tentang permainan alat musik drum. Pembiasaan sikap pada saat latihan maupun pementasan, dan pemilihan repertoar lagu yang dimainkan telah membentuk pola sikap dan perilaku anak.

Salah satunya adalah Arsya peserta didik drum di West Brothers. Menurut penuturan Eros selaku pengajarnya, sejak 
awal belajar drum Arsya sudah diberikan materi pembelajaran drum memainkan lagulagu beraliran rock dengan tempo yang cenderung cepat dan pukulan keras sesuai dengan karakter Arsya yang sangat aktif dan ekspresif. Pembiasaan pengalaman mendengarkan dan memainkan lagu-lagu rock tersebut menjadikan Arsya semakin menggemari musik rock. Menurut keterangan orang tuanya, Arsya setelah beberapa bulan belajar drum di West Brothers saat di rumah memiliki kegemaran baru yaitu mendownload video-video permainan drum band-band rock yang dia sukai seperti Metallica, Guns „n? Roses, Avenged Sevenfold dan sebagainya. Bahkan Arsya lebih tertarik untuk membaca artikelartikel yang berkaitan dengan musik rock daripada pelajaran sekolah. Hal ini menunjukkan bahwa secara tidak langsung telah terjadi proses internalisasi di dalam kegiatan pembelajaran drum yang dijalani oleh Arsya lewat penanaman musik rock yang dilakukan oleh Eros melalui kegiatan belajar mengajar alat musik drum di West Brothers.

Seperti yang telah disampaikan di atas bahwa dalam berkesenian, seorang anak tidak dapat dipaksa, termasuk pada pemilihan instrumen dan jenis lagu yang dimainkan. Begitu pula dalam internalisasi bahwa proses belajar yang dialami seorang anak atau peserta didik drum di West
Brothers adalah tanpa tekanan. Peserta didik menirukan dan menguasai materi pelajaran yang diberikan oleh pengajar dengan kesadaran bahwa apa yang dipelajari memiliki arti dan manfaat dalam pengembangan dirinya.

Juna dan Arta, peserta didik drum kelas TK. Keduanya merupakan teman sebaya yang terjalin saat sama-sama belajar drum di West Brothers. Keduanya tersebut dilatih oleh Oscar yang menggemari musik rock. Dalam setiap kegiatan pembelajaran drum Oscar selalu menekankan kepada kedua peserta didiknya tersebut untuk memukul drum dengan keras saat memainkan lagu rock dengan tempo yang ngebeat atau cepat. Oscar yang memiliki cukup pengalaman manggung bersama band-bandnya terdahulu juga mengarahkan setiap gaya penampilan panggung Juna dan Arta. Menurut Oscar saat peserta didiknya tampil di atas panggung, anak-anak seperti Juna dan Arta tidak sekedar menunjukkan kemampuan bermain drum sebagai peserta didik, namun juga harus menunjukkan sesuatu aksi yang menghibur penonton. Maka dalam pementasan yang diselenggarakan oleh West Brothers, Juna dan Arta selalu menunjukkan gaya dan aksi panggung selayaknya rock star dimulai dari gaya rambut dan kostum ala rocker.

Selain itu juga dipertontonkan atraksi dramatikal pada saat pementasan. 
Salah satu aksi yang pernah ditampilkan yaitu pada saat sebelum mulai tampil, Oscar meminta Juna untuk melemparkan kursi drumnya ke arah samping panggung kemudian dia bermain drum sambil berdiri. Sedangkan Arta melakukan aksinya dengan melemparkan stik drumnya ke arah penonton layaknya artis musisi rock. Dalam pembelajaran drum tersebut telah terjadi proses internalisasi yaitu peserta didik diajari pentingnya sebuah aksi panggung sebagai pendukung penampilan, bahwa berkesenian tidak sekedar melakukan aktifitas seni bermain drum namun juga mampu menghibur penikmatnya sebagai pemenuhan kebutuhan kesenangan.

Irfan atau Eros adalah pengajar drum yang memiliki pengalaman mengajar alat musik drum di West Brothers paling lama yaitu sejak tahun 2006. Irfan akrab dipanggil Eros karena wajahnya yang dianggap memiliki kemiripan dengan seorang gitaris band terkenal Indonesia Sheila On 7 bernama Eros Chandra, dan kebetulan Irfan (Eros) juga sangat menggemari lagu-lagu Sheila On 7. Dalam kegiatan belajar mengajar alat musik drum, Eros paling sering menggunakan lagu Sheila On 7 sebagai bahan materi ajar. Dito salah satu peserta didiknya Eros yang sering mendapatkan materi ajar lagu-lagu Sheila On 7 sejak awal belajar drum saat kelas 2 SD. Kebiasaan dalam memainkan drum lagu
Sheila On 7 menjadikan Dito kemudian ikut menggemari band Sheila On 7. Bahkan West Brothers pernah menyelenggarakan kegiatan pementasan Tribute Sheila On 7 di Solo Pragon Mall khusus menyajikan repertoar lagu-lagu Sheila On 7, dimana pentas tersebut menampilkan 15 anak-anak peserta didik drum West Brothers membawakan repertoar lagu-lagu Sheila On 7. Acara tersebut juga mendapatkan apresiasi dari Pandawa Lima yaitu komunitas penggemar Sheila On 7 (Sheila Genk) yang berada di wilayah kota Solo. Dito merupakan salah satu peserta didik yang menjalani proses internalisasi dimana selain bersosialisasi memainkan peran sebagai peserta didik dan pemain drum, juga memahami serta menghayati lebih mendalam terhadap Sheila On 7, baik lagu maupun perjalanan kesuksesan band tersebut di industri musik Indonesia.

Dalam kegiatan pembelajaran drum di West Brothers telah terjadi internalisasi dimana di dalamnya terdapat sistem budaya (culture system) meliputi gagasan, nilai dan pengetahuan tentang cara bermain drum baik pada saat latihan maupun pementasan termasuk tata cara aksi panggung sebagai pendukung penampilan. Sistem budaya tersebut memiliki fungsi untuk mengendalikan, menanamkan, dan memantapkan tingkah laku atau tindakan peserta didik. Adapun pola aktivitas tingkah 
laku dan tindakan berinteraksi antara peserta didik dengan pengajar dan para musisi lainnya di dalam pembelajaran drum di West Brothers membentuk suatu sistem sosial (social system). Selain itu dalam proses pembelajaran drum juga terdapat sistem personalitas (personality system) yaitu aspek psikologis atau watak pribadi peserta didik saat berinteraksi dengan pengajarnya, dan orang-orang yang berada di lingkungan West Brothers sebagai sebuah kelompok masyarakat.

\section{Tahapan Internalisasi dalam Pembelajaran Drum}

Mengacu pada pendapat Muhaimin (1996) mengenai tahapan internalisasi, terjadinya internalisasi di dalam proses pembelajaran alat musik drum di West Brothers terdiri dari tiga tahapan yaitu :

\section{Tahap transformasi nilai}

Tahap ini merupakan suatu proses yang dilakukan oleh pengajar dalam menyampaikan informasi nilai-nilai yang baik dan kurang baik dalam bermain alat musik drum. Pada tahap ini hanya terjadi komunikasi verbal antara pengajar dan peserta didik. Peserta didik dihadapkan pada dua pilihan nilai,baik dan kurang baik. Sebagai contoh yaitu peserta didik diberikan pengetahuan mengenai teknikteknik cara memegang stik yang terdiri dari dua gaya yaitu traditional grip memiliki keunggulan dalam permainan drum untuk lagu-lagu lembut dan gaya matched grip yang lebih cocok digunakan untuk permainan drum lagulagu rock.

\section{Tahap Transaksi Nilai}

Tahapan ini merupakan suatu tahap pendidikan nilai dengan jalan melakukan komunikasi dua arah yaitu interaksi antara peserta didik dengan pendidik yang berlangsung secara timbal balik. Pada tahap ini peserta didik sudah bisa memilih nilai-nilai yang dianggap sejalan dengan prinsip hidupnya. Misalnya, seorang peserta didik saat memainkan lagu beraliran rock memilih untuk menggunakan gaya memegang stik matched grip karena posisi jari dan tangan pada gaya tersebut dianggap lebih membantu dalam mengolah permainan drum berirama rock dengan tempo cepat.

\section{Tahap Transinternalisasi}

Di tahap ini pendidik dan peserta didik tidak sekedar melakukan komunikasi secara verbal, akan tetapi sudah terjadi proses penanaman sikap mental dan kepribadian dari pengajar terhadap peserta didiknya. Adapun komunikasi kepribadian yang telah tertanam dalam diri peserta didik akan berperan secara 
aktif. Tahap ini lebih nampak di kegiatan pementasan sebagai program pembelajaran melatih mental peserta didik dalam bermain drum di atas panggung baik solo menggunakan minus one maupun bermain bersama dalam format band. Di dalam kegiatan pementasan peserta didik drum diberikan penanaman mental sebagai seorang bintang panggung atau artis musisi pemain drum. Saat di atas panggung seorang peserta didik dituntut untuk memainkan peranan sebagai seorang ,anak band? yang terwujud dalam sikap atau tingkah lakunya memainkan alat musik drum.

\section{Kesimpulan}

Berdasarkan hasil pembahasan yang telah dipaparkan dari tulisan ini diperoleh kesimpulan sebagai berikut :

Seorang anak (individu) dalam hal ini peserta didik drum di West Brothers sebelumnya telah melewati proses sosialisasi primer di lingkungan keluarga dengan memainkan peran sebagai seorang anak anggota keluarga, dimana menggunakan role model dari sikap perilaku orang-orang di dalam lingkungan keluarga, seperti orang tua, saudara, dan teman bermain. Adapun kecenderungan minat dan selera musikal anak yang sudah keluar dari "dunia anak", mulai terbentuk melalui agen sosialisasi keluarga dan teman bermain di lingkungan rumah. Anak sudah tidak lagi terbiasa bahkan mengenal musik yang sesuai dengan "dunia" mereka. Kemudian proses sosialisasi berlanjut di West Brothers sebagai agen sosialisasi yang mana juga sejalan dengan agen sosialisasi keluarga dan teman bermain lingkungan rumah. Sehingga proses sosialisasi yang berlangsung di West Brothers melalui pembelajaran drum tersebut semakin mendukung bahkan memperkuat terbentuknya sikap perilaku anak yang terwujud dalam permainan musik drum.

Proses sosialisasi dan internalisasi berjalan beriringan di dalam kegiatan pembelajaran drum. Selain berinteraksi dengan lebih banyak orang, anak juga memperoleh lebih banyak informasi pengetahuan, pemahaman, dan pengalaman musikal melalui kegiatan pembelajaran drum di West Brothers, baik pada saat kursus, latihan bersama, maupun pementasan. Informasi tersebut meliputi aspek kognitif berupa pengenalan teori-teori musik bermain drum, aspek motorik berupa latihan teknik memukul drum dengan mengkoordinasikan gerakan tangan dan kaki. Selain itu juga terdapat aspek afektif dimana internalisasi berlangsung, yaitu berupa penanaman nilai etika, aturan-aturan dalam bermain drum, serta pemahaman mendalam terhadap jenis musik yang dimainkan. 
Sosialisasi dan internalisasi dalam pembelajaran drum di West Brothers terbentuk melalui proses transmisi budaya musik berupa interaksi belajar mengajar dan pementasan yang membentuk sikap perilaku anak dalam memainkan peranan sebagai peserta didik sekaligus pemain drum. Adapun perilaku anak yang terwujud dalam bentuk permainan drum meliputi pengetahuan dan keterampilan bermain drum, selera musik, serta gaya panggung memiliki kesamaan dengan perilaku pengajar dan musisi yang berada di komunitas West Brothers.

\section{Daftar Pustaka}

Maryati, Kun dan Juju Suryawati. 2006. Sosiologi : Untuk SMA dan MA. Jakarta: Erlangga

Muhaimin, Yahya. 1996. Strategi Belajar Mengajar. Surabaya: Citra Media.

Rohidi, Tjeptjep Rohendi. 1994. Pendekatan Sistem Sosial Budaya Dalam Pendidikan. Semarang: IKIP Semarang Press. 